\title{
Cyclic voltammetry study of trivalent basic chromium sulphate electrolytes contaminated with sulphite
}

\author{
A.C.A. de Vooys ${ }^{a}{ }^{*}$, J.H.O.J. Wijenberg ${ }^{a}$, M.T.M. Koper ${ }^{b}$ \\ a Tata Steel, Research \& Development, IJmuiden Technology Centre, P.O. Box 10.000, 1970, CA, IJmuiden, The Netherlands \\ ${ }^{\mathrm{b}}$ Leiden Institute of Chemistry, Leiden University, P.O. Box 9502, 2300, RA, Leiden, The Netherlands
}

\section{A R T I C L E I N F O}

\section{Article history:}

Received 13 February 2018

Accepted 27 February 2018

Available online 2 March 2018

\section{Keywords:}

Trivalent chromium electrolytes

Sulphite

Platinum electrodes

Competitive adsorption

\begin{abstract}
A B S T R A C T
The discovery of sulphite in basic chromium sulphate, typically used as the source of $\mathrm{Cr}(\mathrm{III})$ ions in trivalent chromium electrolytes, sparked an investigation into the effects of this species on the reactions at a platinum electrode in a $\mathrm{Cr}(\mathrm{III})$-formate electrolyte. The specific adsorption and oxidation-reduction reactions of sulphite were mapped using cyclic voltammetry and linked to competitive adsorption between sulphite, formic acid and the $\mathrm{Cr}(\mathrm{III})$-formate complex.

It was found that sulphite adsorption and reduction/oxidation dominates the cyclic voltammogrammetric response. Formic acid oxidation is completely inhibited as long as sulphite is present at the surface.

A feasible way of removing any sulphite from a contaminated electrolyte is by applying a prolonged reductive current.
\end{abstract}

() 2018 Elsevier Ltd. All rights reserved.

\section{Introduction}

In response to REACH legislation, the plating industry is gradually converting from hexavalent to trivalent chromium electrolytes [1-3]. Obviously, oxidation of $\mathrm{Cr}(\mathrm{III})$ to $\mathrm{Cr}(\mathrm{VI})$ at the anode during the plating process must be ruled out [4-15]. In a recent study, we reported that in trivalent chromium electrolytes with formate as complexing agent, $\mathrm{Cr}(\mathrm{VI})$ is formed at a platinum anode, but not at a titanium anode with a mixed metal oxide (MMO) coating comprising iridium oxide $\left(\mathrm{IrO}_{2}\right)$ and tantalum oxide $\left(\mathrm{Ta}_{2} \mathrm{O}_{5}\right)$ [15].

Using cyclic voltammetry combined with On-Line Electrochemical Mass Spectrometry (OLEMS) measurements, it was observed that at platinum the characteristic 'surface explosion' peak due to oxidation of formate to $\mathrm{CO}_{2}$ is completely suppressed when basic chromium sulphate $\left(\left(\mathrm{CrOHSO}_{4}\right)_{2} \times \mathrm{Na}_{2} \mathrm{SO}_{4}\right)$ is added to a formate solution. This was attributed to adsorption of the $\mathrm{Cr}(\mathrm{III})-$ formate complex to the platinum surface. However, after publication of ref. 15 , the $\mathrm{CO}_{2}$ surface explosion peak was measured in a $\mathrm{Cr}$ (III) electrolyte sample from a plating line, thus in conflict with our previous conclusions. Additionally, we observed that the

\footnotetext{
* Corresponding author.

E-mail address: arnoud.de-vooys@tatasteel.com (A.C.A. de Vooys).
}

current efficiency of the chromium plating process had strongly improved after prolonged use of the trivalent chromium bath. Both findings sparked an investigation into the purity of the basic chromium salt that was used for our study.

Basic chromium salt is industrially prepared by the reduction of $\mathrm{Cr}(\mathrm{VI})$ in the form of sodium dichromate to $\mathrm{Cr}(\mathrm{III})$ with $\mathrm{SO}_{2}$ [16]:

$\mathrm{Na}_{2} \mathrm{Cr}_{2} \mathrm{O}_{7}+\mathrm{H}_{2} \mathrm{O}+3 \mathrm{SO}_{2} \rightarrow\left(\mathrm{CrOHSO}_{4}\right)_{2} \times \mathrm{Na}_{2} \mathrm{SO}_{4}$

An excess of sulphur dioxide is required to ensure chromium is fully reduced to the $3+$ oxidation state. Chemical suppliers use a second reaction to remove the residual sulphur dioxide. However, if present, excess $\mathrm{SO}_{2}$ will result in the formation of sulphurous acid $\left(\mathrm{H}_{2} \mathrm{SO}_{3}\right)$, which may in turn form sulphite anions:

$\mathrm{SO}_{2}+\mathrm{H}_{2} \mathrm{O} \rightarrow \mathrm{H}_{2} \mathrm{SO}_{3} \leftrightarrow 2 \mathrm{H}^{+}+\mathrm{SO}_{3}^{2-}$

Having become aware of the possible presence of sulphite or related species in trivalent chromium electrolytes, it was decided to investigate whether the cyclic voltammetry measurements in our previous study might be affected by a sulphite contamination of the basic chromium salt.

We believe this study is also relevant to other chromium plating studies, as basic chromium sulphate is the common source of $\mathrm{Cr}(\mathrm{III})$ ions in trivalent chromium electrolytes, and therefore the effect of 
traces of sulphite in the electrolyte may have to be considered in other systems as well. From a more scientific point of view, our study gives a better insight into the effect of competitive adsorption on reactivity and selectivity in multi-component electrolytes.

\section{Experimental}

\subsection{Electrolytes}

All chemicals used for preparing the electrolytes were p.a. grade except for the basic chromium(III) sulphate salt ( $\mathrm{CrOH}-$ $\left.\left.\mathrm{SO}_{4}\right)_{2} \cdot \mathrm{Na}_{2} \mathrm{SO}_{4} \cdot \mathrm{H}_{2} \mathrm{O}\right)$ with trade name Trisurfin ${ }^{\circledR}$ supplied by Soda Sanayii A.Ş.

All electrolytes contain $900 \mathrm{mM} \mathrm{Na} \mathrm{SO}_{4}$ as supporting salt and were adjusted to $\mathrm{pH} 2.8$ at $25^{\circ} \mathrm{C}$ by adding sulphuric acid.

\subsection{Cyclic voltammetry measurements}

The working electrode was a mirror polished platinum Rotating Disk Electrode (RDE) tip from Pine Instrument Company with an outer diameter of $5 \mathrm{~mm}$.

Prior to the measurements, the Pt RDE was cleaned in a $0.1 \mathrm{M} \mathrm{H}_{2} \mathrm{SO}_{4}$ electrolyte by repetitive potential scans between the onset of hydrogen evolution on the cathodic side and oxygen evolution on the anodic side until a stable cyclic voltammogram (CV) was obtained.

The potential was controlled by a Metrohm Autolab PGSTAT302N potentiostat. All potentials are reported vs. an Ag/ $\mathrm{AgCl} / \mathrm{KCl}$ (sat'd) electrode. A fine-meshed circular platinum gauze with a diameter of $30 \mathrm{~mm}$ served as counter electrode.

A glass cell with an integrated water jacket connected to a LAUDA Ecoline E 100 circulation thermostat was used to keep the electrolyte at $50^{\circ} \mathrm{C}$.

All cyclic voltammograms were recorded with a rotation rate of 9 rps and a scan rate of $100 \mathrm{mV} \mathrm{s}^{-1}$.

\subsection{Electrolysis experiments}

To study the purification process of the $\mathrm{Cr}$ (III) electrolyte and the removal of sulphite in time, electrolysis experiments were executed in a flow channel cell. To study the oxidation resp. reduction of sulphite, electrolysis experiments were done in a twocompartment cell with separated electrodes.

\subsubsection{Flow channel cell}

The flow channel cell is designed for producing A4 sheet samples under controlled mass transfer conditions. The electrolyte volume is $200 \mathrm{l}$ and the channel gap is $10 \mathrm{~mm}$. The flow rate was $8 \mathrm{~m}^{3} \mathrm{~h}^{-1}$ corresponding to a liquid velocity in the channel cell of $1.1 \mathrm{~m} \mathrm{~s}^{-1}$.

The anode was titanium with a catalytic mixed metal oxide (MMO) coating comprising iridium oxide $\left(\mathrm{IrO}_{2}\right)$ and tantalum oxide $\left(\mathrm{Ta}_{2} \mathrm{O}_{5}\right)$ supplied by MAGNETO special anodes B.V. The catalytic coating thickness was $5 \mu \mathrm{m}$. A low-carbon mild steel sheet (NEN-EN 10205 ) with a surface area of $300 \mathrm{~mm} \times 200 \mathrm{~mm}$ and a gauge of $0.183 \mathrm{~mm}$ was used as the cathode. During electrolysis, the electrolyte temperature was kept at $50^{\circ} \mathrm{C}$.

An SM 30-100 D Power Supply from Delta Elektronika was used for applying the current.

\subsubsection{Two-compartment cell}

Both compartments were separated by a glass frit allowing migration of ions, but preventing convective mixing of the catholyte and anolyte. A low-carbon mild steel sample $(20 \mathrm{~mm} \times 20 \mathrm{~mm})$ of which one side was insulated by means of tape was used as cathode and titanium with an MMO coating (see previous section) was used as anode. The electrolyte in the compartment holding the cathode was moderately agitated by a magnetic stirrer. The volume of the catholyte was $100 \mathrm{ml}$.

During electrolysis, the electrolyte temperature was kept at $50{ }^{\circ} \mathrm{C}$.

The current was controlled by a Metrohm Autolab PGSTAT302N potentiostat/galvanostat.

\section{Results}

\subsection{Comparison of a fresh and a used Cr(III) electrolyte}

The cyclic voltammogram (CV) of a freshly prepared $\mathrm{Cr}$ (III) electrolyte is given in Fig. 1 (blue curve). The oxidation of formic acid to $\mathrm{CO}_{2}$ is clearly suppressed, which can be explained by assuming that some species is strongly adsorbed at the platinum surface. A CV was recorded of a $\mathrm{Cr}$ (III) electrolyte sample from a plating line after several hours of operation (Fig. 1: red curve). Clearly, this CV is very different from the CV of a fresh $\mathrm{Cr}(\mathrm{III})$ electrolyte: the characteristic features of formic acid oxidation are clearly present, especially the $\mathrm{CO}_{2}(\mathrm{~g})$ surface explosion peak at $0.2 \mathrm{~V}$ in the negative-going scan.

The composition of both electrolytes is supposedly similar, so a chromium-formate complex is present in both cases. This is not in agreement with our previous hypothesis that the chromium(III)formate complex adsorbs strongly at the platinum surface [15]. The following experiments are aimed at checking the hypothesis that sulphite is the strongly adsorbing species responsible for the changes in the $\mathrm{CV}$.

\subsection{Sulphite oxidation}

Fig. 2 shows a cyclic voltammogram of a $900 \mathrm{mM}$ sodium sulphate solution ( $\mathrm{pH} 2.8$ ) with various sodium sulphite additions. The reference graph without any sulphite shows a limiting current density plateau due to the reduction of oxygen below $0.25 \mathrm{~V}$.

When sulphite is added, the current rises steeply at $0.3 \mathrm{~V}$, reaching diffusion limitation at $0.5 \mathrm{~V}$. At this stage, the current becomes proportional to the concentration (see inset). The current decreases at potentials above $0.9 \mathrm{~V}$ due to the formation of platinum oxide and/or adsorption of a sulphur containing species. The increase in oxidative current between 0.9 and $0.45 \mathrm{~V}$ during the

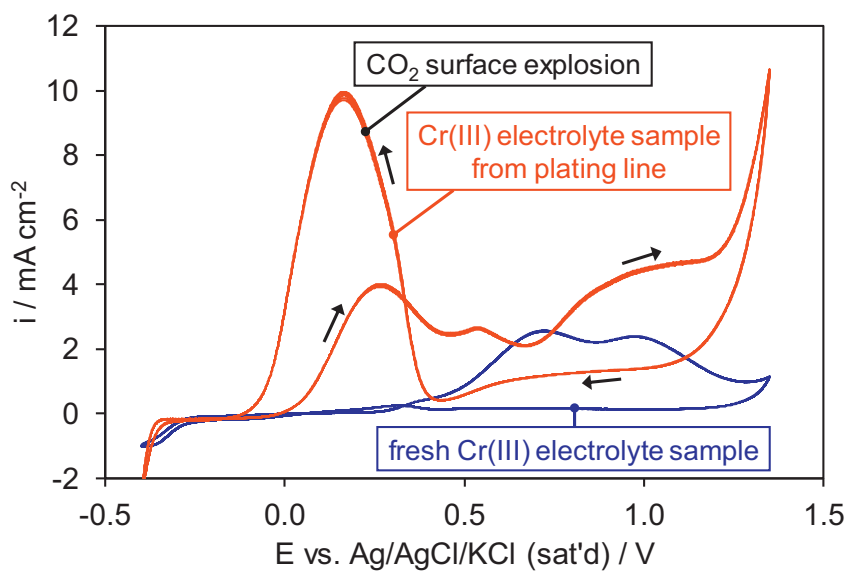

Fig. 1. Cyclic voltammograms of a fresh $\mathrm{Cr}$ (III) electrolyte sample (blue curve) and a $\mathrm{Cr}$ (III) sample from a plating line (red curve) with similar composition ( $900 \mathrm{mM}$ $\mathrm{Na}_{2} \mathrm{SO}_{4}+400 \mathrm{mM} \mathrm{CrOHSO}+400 \mathrm{mM} \mathrm{HCOONa}$ ). (For interpretation of the references to colour in this figure legend, the reader is referred to the Web version of this article.) 


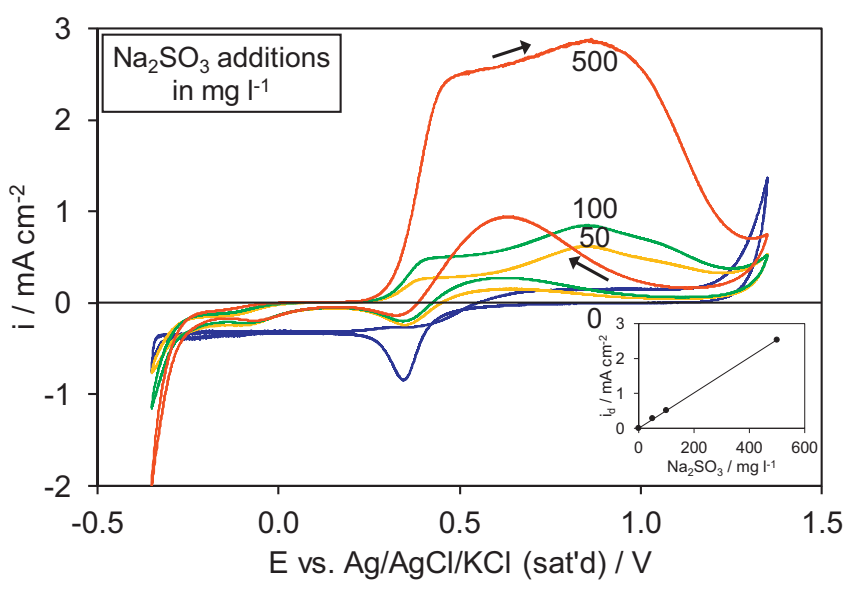

Fig. 2. Cyclic voltammograms in a $900 \mathrm{mM} \mathrm{Na} 2 \mathrm{SO}_{4}$ electrolyte with various $\mathrm{Na}_{2} \mathrm{SO}_{3}$ additions (blue curve: 0 , orange curve: 50 , green curve: 100 , red curve $500 \mathrm{mg} \mathrm{l}^{-1}$ $\mathrm{Na}_{2} \mathrm{SO}_{3}$ ). Inset: diffusion-limited current density vs. $\mathrm{Na}_{2} \mathrm{SO}_{3}$ concentration. (For interpretation of the references to colour in this figure legend, the reader is referred to the Web version of this article.)

negative sweep (potentials where platinum oxides are not yet reduced) may be an indication of the latter.

The addition of sulphite blocks the oxygen reduction; the current becomes zero between 0 and $0.2 \mathrm{~V}$. Below $0 \mathrm{~V}$ a reductive current is measured with an additional wave at $-0.2 \mathrm{~V}$.

The entire CV shows that sulphite adsorbs strongly on platinum, and is readily oxidised.

Cycling between $-0.2 \mathrm{~V}$ resp. $-0.35 \mathrm{~V}$ shows a strong effect on the subsequent oxidation current of sulphite (Fig. 3). We infer that sulphite can form intermediates that poison subsequent oxidation. These intermediates are reduced below $-0.2 \mathrm{~V}$, activating the surface for rapid oxidation of sulphite.

The cyclic voltammogram and the effect of increased concentration are in line with literature [17,18], in which the strongly adsorbed intermediate was assumed to be pure sulphur.

\subsection{Effect of sulphite on formic acid oxidation}

The CV of formic acid on platinum (Fig. 4: red curve) has been discussed in detail in our previous publication and references

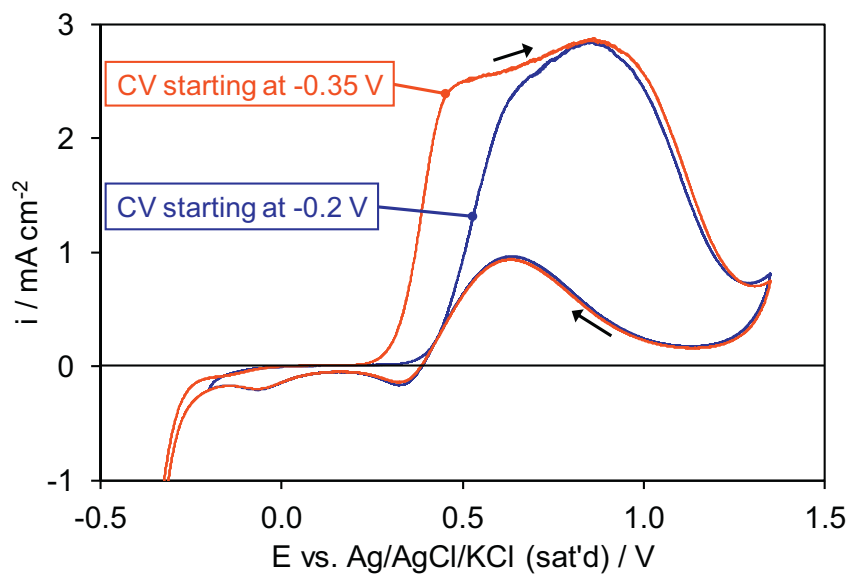

Fig. 3. Cyclic voltammograms in a $900 \mathrm{mM} \mathrm{Na} 2 \mathrm{SO} 4$ electrolyte with $500 \mathrm{mg} \mathrm{l}^{-1} \mathrm{Na}_{2} \mathrm{SO}_{3}$ and a lower vertex potential of -0.2 (blue curve) and $-0.35 \mathrm{~V}$ (red curve). (For interpretation of the references to colour in this figure legend, the reader is referred to the Web version of this article.)

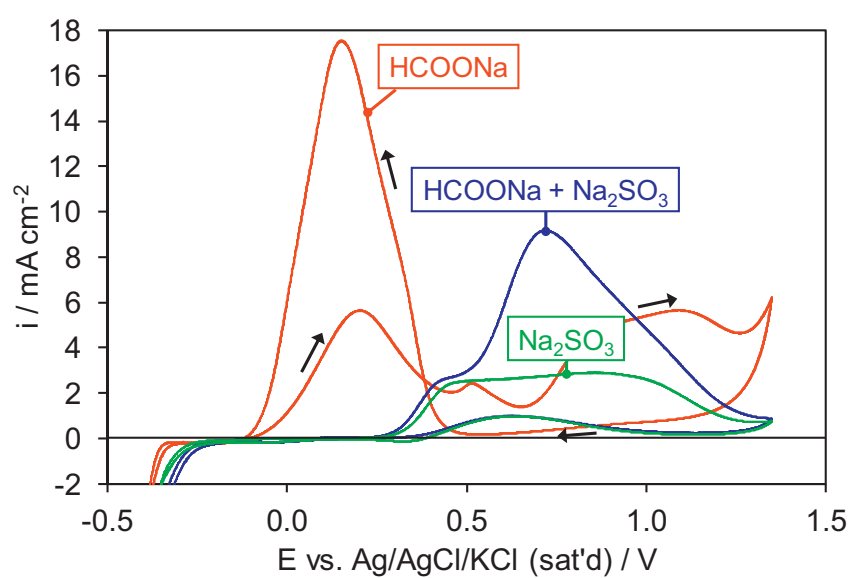

Fig. 4. Cyclic voltammograms in electrolytes with the following compositions: $900 \mathrm{mM} \mathrm{Na}_{2} \mathrm{SO}_{4}+200 \mathrm{mM}$ HCOONa (red curve), $900 \mathrm{mM} \mathrm{Na}_{2} \mathrm{SO}_{4}+200 \mathrm{mM}$ $\mathrm{HCOONa}+500 \mathrm{mg} \mathrm{l}^{-1} \mathrm{Na}_{2} \mathrm{SO}_{3}$ (blue curve) and $900 \mathrm{mM} \mathrm{Na}_{2} \mathrm{SO}_{4}+500 \mathrm{mg} \mathrm{l}^{-1} \mathrm{Na}_{2} \mathrm{SO}_{3}$ (green curve). (For interpretation of the references to colour in this figure legend, the reader is referred to the Web version of this article.)

therein [15]. The main characteristic feature is the high oxidation current at $+0.2 \mathrm{~V}$. This 'surface explosion' is the result of the combination of three conditions: 1 . a relatively high overpotential for formic acid oxidation, 2 . the availability of metallic platinum and 3. the absence of $\mathrm{CO}$ poisoning of the surface.

When sulphite is added (blue curve), the oxidation of formic acid on metallic platinum is completely inhibited: the current is zero between -0.2 and $+0.4 \mathrm{~V}$. This shows that sulphite is adsorbed strongly on platinum, much stronger than formic acid.

An oxidative current is observed above $0.4 \mathrm{~V}$ at the same potential where sulphite itself is oxidised: the blue curve (with formic acid) is higher than the green curve (without formic acid). The additional current is most likely related to formic acid oxidation, which is only possible after sulphite is oxidised and removed from the surface.

\subsection{Addition of basic chromium salt}

The addition of $\mathrm{Cr}$ (III) to a sulphite containing electrolyte is

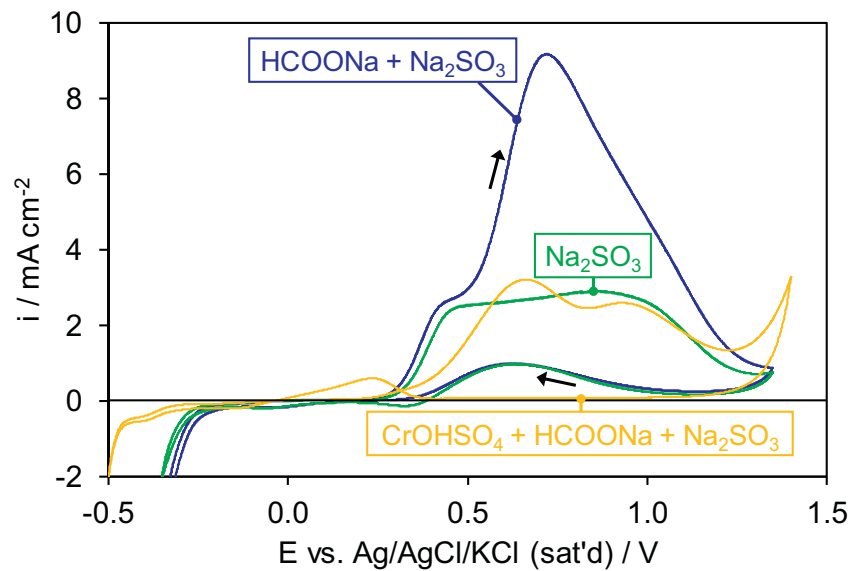

Fig. 5. Cyclic voltammograms in electrolytes with the following compositions: $900 \mathrm{mM} \mathrm{Na}_{2} \mathrm{SO}_{4}+200 \mathrm{mM} \mathrm{HCOONa}+500 \mathrm{mg} \mathrm{l}^{-1} \mathrm{Na}_{2} \mathrm{SO}_{3}$ (blue curve), $900 \mathrm{mM}$ $\mathrm{Na}_{2} \mathrm{SO}_{4}+500 \mathrm{mg} \mathrm{l}^{-1} \mathrm{Na}_{2} \mathrm{SO}_{3}$ (green curve) and $900 \mathrm{mM} \mathrm{Na}_{2} \mathrm{SO}_{4}+400 \mathrm{mM}$ $\mathrm{CrOHSO}_{4}+600 \mathrm{mM} \mathrm{HCOONa}+500 \mathrm{mg} \mathrm{l}^{-1} \mathrm{Na}_{2} \mathrm{SO}_{3}$ (orange curve). (For interpretation of the references to colour in this figure legend, the reader is referred to the Web version of this article.) 
shown in Fig. 5. The main observation is the blocking of formic acid oxidation on metallic platinum, in line with the previous curves. The oxidation of sulphite between 0.3 and $0.5 \mathrm{~V}$ in the positive sweep is slightly reduced, as well as the reductive current between -0.3 and $-0.5 \mathrm{~V}$. Both are an indication that some species is adsorbed at the surface, which is not reduced at negative potentials (Fig. 3 showed that adsorbed sulphite itself is reduced at those potentials).

An oxidative current in two waves is seen between 0.5 and $1.0 \mathrm{~V}$ : OLEMS measurements have demonstrated that the second wave is mainly $\mathrm{CO}_{2}$ formation (Fig. 6).

Fig. 6 was recorded with a fresh electrolyte. Recording an OLEMS measurement of a used electrolyte was not performed because the CV of a used electrolyte (Fig. 1: red curve) is identical to the CV of formic acid (Fig. 4: red curve). Thus, the only reactions occurring in a used electrolyte are those of formic acid.

A final difference is an increase in oxidative current above $1.3 \mathrm{~V}$, which does not occur in the absence of $\mathrm{Cr}$ (III). It is also demonstrated that $\mathrm{Cr}(\mathrm{III})$ can be oxidised to $\mathrm{Cr}(\mathrm{VI})$ on platinum electrodes under steady state current. We therefore assign this current, at least in part, to the oxidation of $\mathrm{Cr}(\mathrm{III})$ to $\mathrm{Cr}(\mathrm{VI})$.

Ideally a graph of $\mathrm{Cr}(\mathrm{III})$ without the sulphite contamination would be recorded. Unfortunately, such salts are not available: they are either poorly soluble or have other pollutants, like organic acids.

Our previous publication stated that the second peak of the cyclic voltammogram (at $0.9 \mathrm{~V}$ ) is linked purely to the formation of $\mathrm{CO}_{2}$, whereas the first peak is in part due to a different adsorption process. At the time we assumed it was the oxidative adsorption of the $\mathrm{Cr}$ (III)-formate complex. However, our new results indicate that this current is rather linked to the oxidation of sulphite at the electrode, which blocks the oxidation for formic acid.

\subsection{Removal of sulphite from $\mathrm{Cr}(\mathrm{III})$ electrolyte by electrolysis}

\subsubsection{Electrolysis experiments in flow channel cell}

Because we noticed that the $\mathrm{CV}$ of a fresh $\mathrm{Cr}(\mathrm{III})$ electrolyte sample is very different from the $\mathrm{CV}$ of a $\mathrm{Cr}$ (III) electrolyte sample from a plating line after several hours of operation, as shown in Fig. 1, a well-defined electrolysis experiment was set-up in a flow channel cell.

The $\mathrm{Cr}$ (III) plating process is assumed to be based on a fast, stepwise deprotonation of the water ligands in the $\mathrm{Cr}$ (III)-complex ion induced by a surface $\mathrm{pH}$ increase as a result of the hydrogen evolution reaction [3]. This mechanism leads to the existence of a

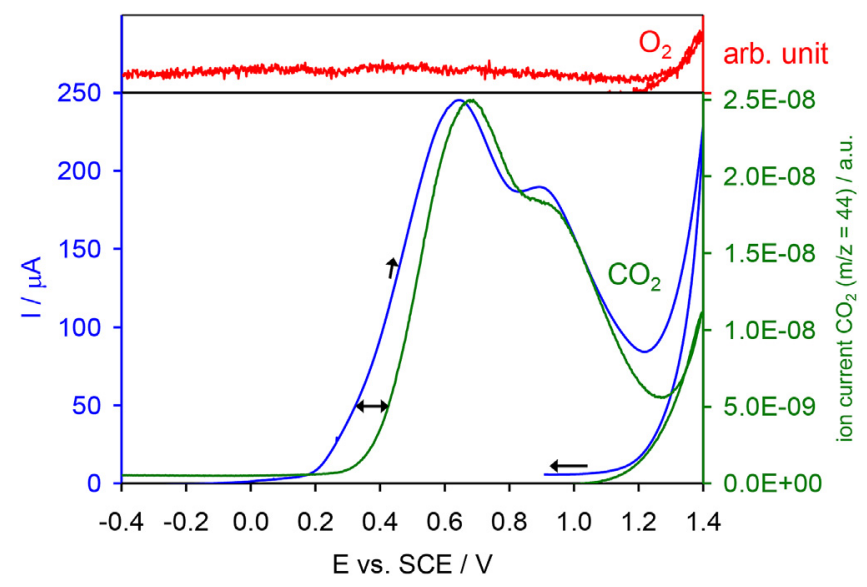

Fig. 6. OLEMS measurement of $\mathrm{CO}_{2}$ and $\mathrm{O}_{2}$ in $\mathrm{Cr}(\mathrm{III})$-formate electrolyte $(900 \mathrm{mM}$ $\mathrm{Na}_{2} \mathrm{SO}_{4}+400 \mathrm{mM} \mathrm{CrOHSO}{ }_{4}+600 \mathrm{mM} \mathrm{HCOONa}$ ) for a stationary Pt electrode at a scan rate of $1 \mathrm{mV} \mathrm{s}^{-1}$ obtained from ref. 15 .

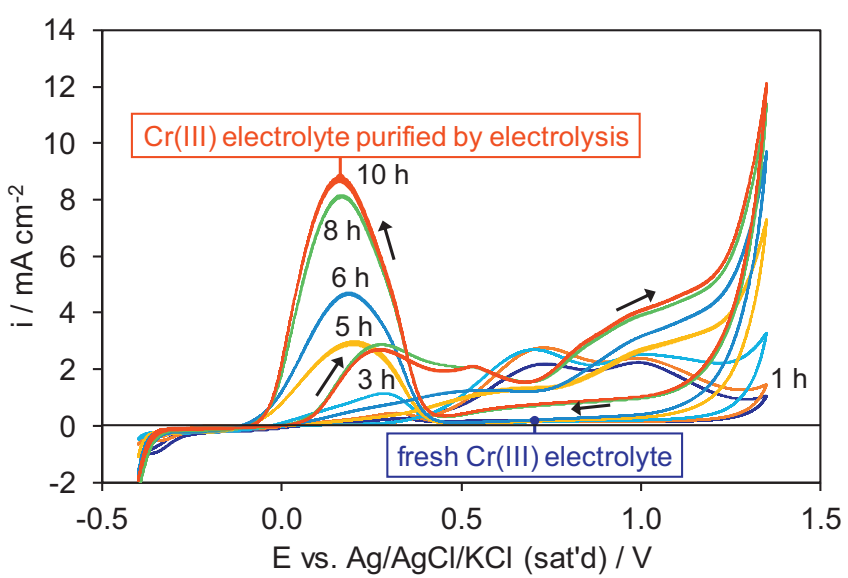

Fig. 7. Cyclic voltammograms of electrolyte samples from flow channel cell.

so-called 'regime I', wherein no chromium is deposited even though an electrical current is applied. In regime I, besides hydrogen evolution, the following acid-base reaction takes place [3]:

$$
\left[\mathrm{Cr}(\mathrm{HCOO})\left(\mathrm{H}_{2} \mathrm{O}\right)_{5}\right]^{2+}+\mathrm{OH}^{-} \rightarrow\left[\mathrm{Cr}(\mathrm{HCOO})(\mathrm{OH})\left(\mathrm{H}_{2} \mathrm{O}\right)_{4}\right]^{+}+\mathrm{H}_{2} \mathrm{O}
$$

A current density of $10 \mathrm{~A} \mathrm{dm}^{-2}$ within regime I was chosen for purification of the electrolyte. Each hour $100 \mathrm{ml}$ electrolyte was sampled for recording a CV. In Fig. 7, the CVs of the electrolyte samples are plotted. Clearly, the CV gradually transforms to an identical shape as the $\mathrm{CV}$ of a $\mathrm{Cr}(\mathrm{III})$ electrolyte sample from a plating line after several hours of operation plotted in Fig. 1. This is attributed to the removal of sulphite from the electrolyte.

\subsubsection{Electrolysis experiments in two-compartment cell}

To elucidate whether purification of the electrolyte proceeds via reduction or oxidation of sulphite, an electrolysis experiment was executed in a two-compartment cell.

A current density of $10 \mathrm{Adm}^{-2}$ was applied for $4 \mathrm{~h}$. During electrolysis, the $\mathrm{pH}$ of the catholyte had increased from 2.8 to 4.7 due to hydrogen evolution $\left(4 \mathrm{H}^{+}+4 \mathrm{e}^{-} \rightarrow 2 \mathrm{H}_{2}\right)$ and conversely the $\mathrm{pH}$ of the anolyte had decreased to 2.3 due to oxygen evolution $\left(2 \mathrm{H}_{2} \mathrm{O} \rightarrow \mathrm{O}_{2}+4 \mathrm{H}^{+}+4 \mathrm{e}^{-}\right)$.

In Fig. 8, the CVs of the catholyte and anolyte are plotted.

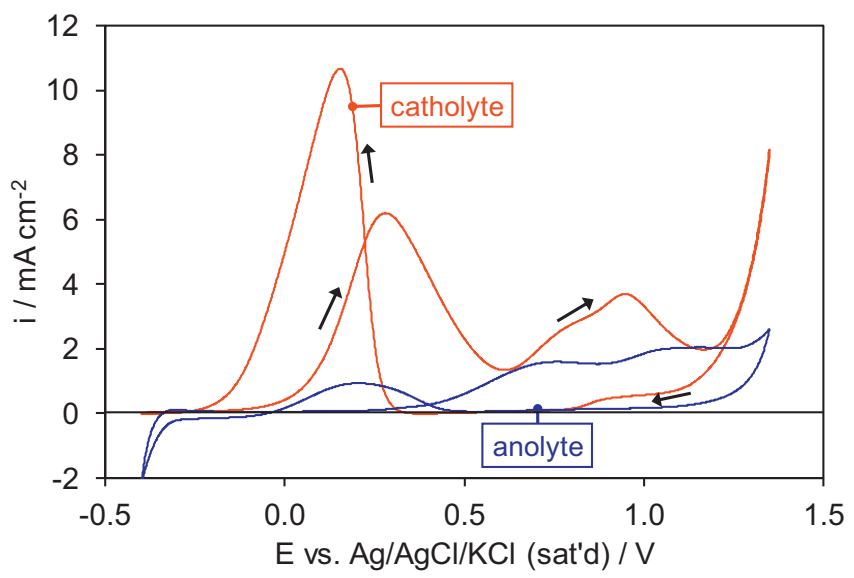

Fig. 8. Cyclic voltammograms of catholyte (red curve) and anolyte (blue curve). (For interpretation of the references to colour in this figure legend, the reader is referred to the Web version of this article.) 


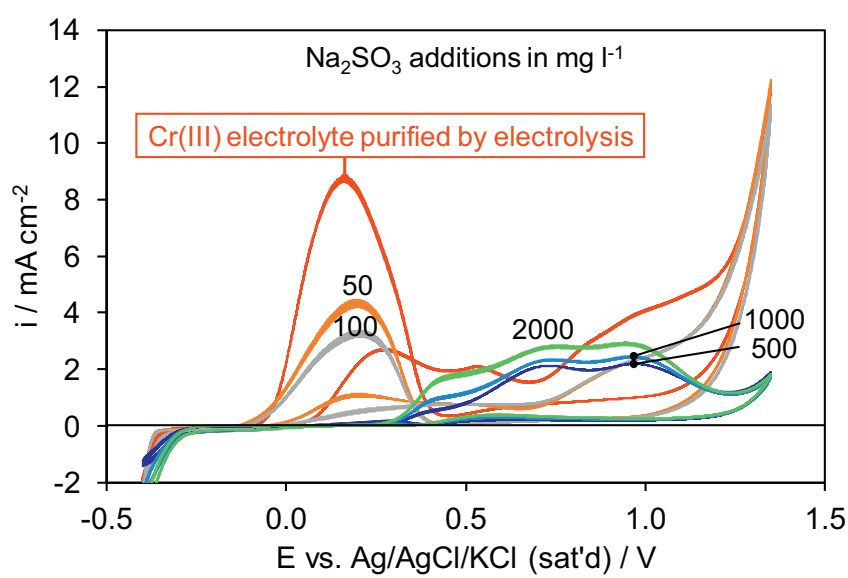

Fig. 9. Cyclic voltammograms of purified electrolyte with $\mathrm{Na}_{2} \mathrm{SO}_{3}$ additions as indicated.

Unmistakably, the $\mathrm{CO}_{2}(\mathrm{~g})$ surface explosion peak arises in the $\mathrm{CV}$ of the catholyte, which proofs that sulphite is reduced to hydrogen sulphide:

$\mathrm{SO}_{3}^{2-}+8 \mathrm{H}^{+}+6 \mathrm{e}^{-} \rightarrow \mathrm{H}_{2} \mathrm{~S}+3 \mathrm{H}_{2} \mathrm{O}$

This experiment also explains the characteristic smell of $\mathrm{H}_{2} \mathrm{~S}$ that is only experienced during the first hours after a fresh $\mathrm{Cr}$ (III) electrolyte is put into operation.

\subsection{Adding sulphite to purified Cr(III) electrolyte}

As a final confirmation of the importance of sulphite, sodium sulphite was intentionally added stepwise to purified electrolyte (Fig. 9). The $\mathrm{CO}_{2}$ surface explosion peak is completely suppressed after adding $500 \mathrm{mg} \mathrm{l}^{-1} \mathrm{Na}_{2} \mathrm{SO}_{3}$ to the electrolyte. The CV of purified electrolyte with $500 \mathrm{mg} \mathrm{l}^{-1} \mathrm{Na}_{2} \mathrm{SO}_{3}$ added is almost identical to the CV of fresh electrolyte (Fig. 10).

\section{Discussion and conclusions}

The oxidation of sulphite clearly occurs at high rates on metallic platinum, like the oxidation of formic acid. When the two species are mixed, the features of sulphite dominate the cyclic voltammogram up to $0.6 \mathrm{~V}$, which can be attributed to its stronger

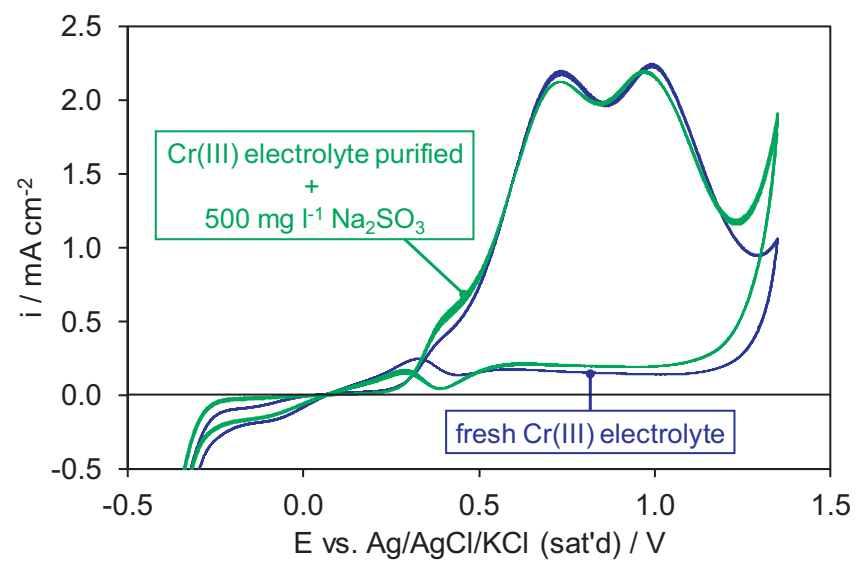

Fig. 10. Cyclic voltammograms of fresh electrolyte and purified electrolyte with $500 \mathrm{mg} \mathrm{l}^{-1} \mathrm{Na}_{2} \mathrm{SO}_{3}$ added. adsorption. It is therefore logical to attribute the first peak of the cyclic voltammogram in the presence of $\mathrm{Cr}(\mathrm{III})+$ formic acid + sulphite to the oxidation of adsorbed sulphite.

Above $0.6 \mathrm{~V}$ the cyclic voltammogram assumes the features of formic acid oxidation: the steady-state oxidation rate is replaced by a peak associated with $\mathrm{CO}_{2}$ formation. This $\mathrm{CO}_{2}$ is indeed observed in the OLEMS measurement as the second peak.

Finally, if the sulphite is removed by electrolysis, the cyclic voltammogram adopts the characteristic shape of that of formic acid.

These observations falsify the assumption in our previous publication that the $\mathrm{Cr}$ (III)-formic acid complex adsorbs strongly at the platinum electrode. The hindrance of chromium deposition on a steel electrode in the presence of sulphite can be explained by assuming that preferential adsorption of sulphite also occurs on steel. Several mechanisms are possible: adsorbed sulphite might block the adsorption of the $\mathrm{Cr}$ (III)-complex and/or interfere with the $\mathrm{pH}$-gradient near the electrode (a requirement for chromium deposition that takes place via acid/base reactions [3]). Strong specific adsorption of sulphite to the steel electrode is in line with the high current efficiency of its removal: without specific adsorption it would be expected that transport of sulphite ions to the electrode would be limiting at low concentrations, which is in contrast to what is measured.

Purification of a fresh $400 \mathrm{mM} \mathrm{Cr}$ (III) electrolyte in the flow cell experiment (see $\S 3.5 .1$ ) was completed after $10 \mathrm{~h}$. Assuming a pollution of $500 \mathrm{mg} \mathrm{l}^{-1} \mathrm{Na}_{2} \mathrm{SO}_{3}$ and a six-electron reduction reaction, the current efficiency for sulphite removal is about $21 \%$. This high current efficiency is in line with strong specific adsorption of sulphite onto the cathode. A much lower number would be expected without specific adsorption as the probability of the sulphite ion interacting with the electrode decreases with concentration.

$500 \mathrm{mg} \mathrm{l}^{-1} \mathrm{Na}_{2} \mathrm{SO}_{3}$ corresponds to $4 \mathrm{mM}$ vs. $400 \mathrm{mM} \mathrm{Cr}$ (III), which is a pollution of $1 \mathrm{~mol}-\%$ of the chromium salt. This number might seem high, but is understandable when realising the chemical producers are very keen on avoiding trace amounts of $\mathrm{Cr}(\mathrm{VI})$ in their chemicals.

Even though the $\mathrm{Cr}$ (III) complex adsorbs weakly, the oxidation of the $\mathrm{Cr}(\mathrm{III})$ ion at potentials above $1.2 \mathrm{~V}$ has been demonstrated, both in the presence and absence of sulphite. The formation of $\mathrm{Cr}(\mathrm{VI})$ under steady state oxidative currents has been proven earlier. Both features are absent on iridium-based mixed metal oxide electrodes. The exact reason for this difference in catalytic activity is unexplained yet.

\section{References}

[1] T. Petrya, R. Knowlesa, R. Meads, An analysis of the proposed REACH regulation, Regul. Toxicol. Pharm 24 (2006) 24-32.

[2] Z. Zeng, A. Liang, J. Zhang, A review of recent patents on trivalent chromium plating, Recent Pat. Mater. Sci. 2 (2009) 50-57.

[3] J.H.O.J. Wijenberg, M. Steegh, M.P. Aarnts, K.R. Lammers, J.M.C. Mol, Electrodeposition of mixed chromium metal-carbide-oxide coatings from a trivalent chromium-formate electrolyte without a buffering agent, Electrochim. Acta 173 (2015) 819-826.

[4] S. Survilienè, O. Nivinskienè, A. Češunienè, A. Selskis, Effect of $\operatorname{Cr}(\mathrm{III})$ solution chemistry on electrodeposition of chromium, J. Appl. Electrochem. 36 (2006) 649-654.

[5] J. Ward, I. Christie, Aqueous chromium plating baths, Great Britain Patent 1333714 , Oct. 17, 1973.

[6] J. Gyllenspetz, S. Renton, Trivalent Chromium Electroplating Baths and Electroplating Therefrom, United States Patent 3954574, May 4, 1976.

[7] D. Lashmore, Process and Bath for Electroplating Nickel-Chromium Alloys, United States Patent 4461680, Jul. 24, 1984.

[8] D. Lashmore, I. Weisshaus, E. Namgoong, Electrodeposition of Chromium from a Trivalent Electrolyte, United States Patent 4804446, Feb. 14, 1989.

[9] G. Shahin, A. Jones, Deposition of Chromium Oxides from a Trivalent Chromium Solution, European Patent 747510, Dec. 11, 1996.

[10] N.M. Martyak, Deposition of Chromium Oxides from a Trivalent Chromium Solution Containing a Complexing agent for a Buffer, United States Patent 
6004448, Dec. 21, 1999.

[11] T. Pearson, S. Handy, Process for Plating Chromium from a Trivalent Chromium Plating bath, United States Patent 20100108532, May 6, 2010.

[12] J.H.O.J. Wijenberg, I. Portegies Zwart, A.C.A. de Vooys, J.P. Penning, M. Steegh, Chromium-chromium Oxide Coatings Applied to Steel Substrates for Packaging Applications and a Method for Producing Said Coatings, W02014/ 079909, 30 May 2014.

[13] J.H.O.J. Wijenberg, I. Portegies Zwart, A.C.A. de Vooys, J.P. Penning, M. Steegh, Chromium-chromium Oxide Coatings Applied to Steel Substrates for Packaging Applications and a Method for Producing Said Coatings, W02014/ 079910, 30 May 2014.

[14] J.H.O.J. Wijenberg, Method for Manufacturing Chromium-chromium Oxide Coated Substrates, WO2014/202316, 24 December 2014.
[15] J.H.O.J. Wijenberg, A.C.A. de Vooys, R. Kortlever, M.T.M. Koper, Oxidation reactions in chromium(III) formate electrolytes at platinum and at a catalytic mixed metal oxide coating of iridium oxide and tantalum oxide, Electrochim. Acta 213 (2016) 194-200 and references cited therein.

[16] B. Chandrasekaran, J. Raghava Rao, K.J. Sreeram, Balachandran Unni Nair, T. Ramasami, Chrome tanning: state-of-art on the material composition and characterization, J. Sci. Ind. Res. 58 (1999) 1-10.

[17] T. Hemmingsen, The electrochemical reaction of sulphur-oxygen compounds - part I. A review of literature on the electrochemical properties of sulphur/ sulphur-oxygen compounds, Electrochim. Acta 37 (1992) 2775-2784.

[18] T. Hemmingsen, The electrochemical reaction of sulphur-oxygen compounds - part II. Voltammetric investigation performed on platinum, Electrochim. Acta 37 (1992) 2785-2790. 